\title{
ACCOUNTING CONSERVATISM AND FINANCIAL PERFORMANCE OF NIGERIAN DEPOSIT MONEY BANKS: AN ANALYSIS OF RECENT ECONOMIC RECESSION
}

\author{
Lawal Aminu \\ Department of Accounting \\ Kaduna State University (KASU)-Nigeria \\ Shehu Usman Hassan PhD \\ Department of Accounting \\ Kaduna State University (KASU)-Nigeria
}

\begin{abstract}
This study explores the relationship between Accounting conservatism and Bank performance in Nigeria. The study uses ex-post facto research design in a sample of 10 Nigerian deposit money banks (NDMBs). Secondary data for a period of 5 years (2012-2016) was used. The study model examined the relationship between the independent variables (Accounting conservatism) and the dependent variable (Bank performance), by applying the Advance panel Multiple regression analysis (Panel Corrected Standard Error).The results obtained from this research indicate that there is a significant relationship between accounting conservatism and Bank performance in Nigeria. From the result conditional accounting conservatism $(C-A C C)$ has a positive relationship with Bank performance (ROA) while unconditional accounting conservatism (UC-ACC) is negatively related to Bank performance (ROA). The study concluded that there is a significant relationship between accounting conservatism and bank performance in Nigeria. The study suggest that Managers of NDMBs should use conditional conservatism as a means to manage information asymmetry in their financial reporting strategies. Also it is recommended that accounting standard setters and bank regulators should consider the effects of unconditional accounting conservatism on banks performance when designing rules and regulations for banks.
\end{abstract}

Keywords: Accounting conservatism, Conditional accounting conservatism, Unconditional accounting conservatism, Bank performance, Nigerian deposit money banks (NDMBs).

\section{Introduction}

Due to the current global challenges which translated itself to several economic distortions; rapidly increasing unemployment rates, a mitigation of commodity prices, a fall of international trade and one of the most important consequences of all is a lack of trust of the public in financial institutions and banks. The public began to set question marks on management policies, strategies and ethical behaviour. Business operations of financial institutions were largely based on the presumptions of stable economic environments and strong economic performance. Nevertheless these optimistic business practices led to an economic crisis and the negative distortions are still felt today.

It is no longer an argument as to whether the accounting conservatism has numerous advantages for companies or firm that practice it, because prior body of empirical literatures has shown that accounting conservatism has positive influence on firm's economic profit (Lawal \& Shehu, 2016) as it has been found not to be detrimental to the shareholders value because It plays an important role in monitoring senior managers (Bushman \& Smith, 2001), contributing toward making moral hazard problems better and to decrease the problems created by information asymmetries (lara, Osma \& Penalva, 2016), and, it facilitates the estimation of firms' future cash flows. These 
effects are expected to increase firm value by improving firm's investment decisions (Bushman \& Smith, 2001 and Lambert, Leuz \& Verrecchia, 2007). Watts (2003) studied conservatism in accounting for decades and in his twopart series paper of 2003, Watts extensively elaborates on the main explanations for accounting conservatism and presents arguments that the accounting conservatism principle still is very significant in improving financial reporting.

Conservatism is the difference between the recognition of profits against losses. In its most extreme manner all loses should be expected and no gains should be expected (Watts 2003; Saeed, Khadije \& Mohammad, 2013 and Lawal \& Shehu, 2016). The recognition of losses should take place when it is assumed that these losses will occur, even when there is no legal claim for this. Practically this means that auditors need a higher degree of confirmation to recognize good information as gains than bad information as losses (Basu 1997). This interpretation of conservatism is found in many accounting standards and concepts. For instance, in the Statement of Financial Accounting Concepts (FASB 1980) it is stated that in the case of equally like estimations of payments or receiving's in the future conservatism obliges to use the less optimistic estimation. The Accounting Research Board (ARB) states that transitions in cost predictions should be instantly recognized by firms if these transitions result in future expected losses, while not if they result in future gains. Thus conservatism results in a greater probability of timely accounting recognition of bad news than for good news (Basu 1997). Alternatively conservatism implies reporting the highest values of liabilities and costs and reporting the lowest values of assets and revenues (Lalbar, Mehdi, \& Karamali, 2012 and Lawal \& Shehu, 2016).

In my opinion it would be of great benefit to further explore the effects of this important and longstanding principle in relation with the performance of banks during this present financial recession in Nigeria. However, in the literature on financial institutions there are only two papers that are related to this paper that examined the relationship between the conservatism (conditional) and the bank performance (Hughes, Lang, Moon \& Pagano, 1997; El Allali, 2010). However, these papers did not examine link between unconditional conservatism and bank performance. Therefore, unlike the previous researches this paper examines the relation between accounting conservatism components (conditional and unconditional) and financial performance of Nigerian deposit money banks (NDMBs). Similarly, despite the number of the studies so far, that examines the relationship between the Accounting conservatism and different variables in a different geographical environment at different time. There is no empirical studies' so far examining the effect of accounting conservatism on Banks performance in Nigeria. Researchers on banks performance have offered a variety of models for measuring performance in banks, however little or no consensus have been reached as to which approach could be used to described as valid measurement of performance in banks. However, Adah \& Thompson, (2016), Sanaa, (2016), Mudiarasan, Ali \& Ananda, (2010), Halex (2007), Woolridge, Randall \& Gray, (2006), Maiturare (2004) and Evanoff \& Fortier (1988) believes that return on asset (ROA) is the best measurement of banks performance. Therefore, ROA is used in this study as a measure of bank performance. For the purpose of this study we raised the following questions: What is the relationship between accounting conservatism and ROA of listed NDMBs? To what extent does Conditional conservatism has impact on ROA of listed NDMBs? And what influence does Unconditional conservatism has on ROA of listed NDMBs?

The main objective of this paper is to determine the relationship between Accounting Conservatism and ROA of NDMBs. Other specific objectives are:

i. To investigate the impact of conditional accounting conservatism on ROA of listed NDMBs.

ii. To examine the impact of unconditional accounting conservatism on ROA of listed NDMBs.

In line with the objectives of the study, the following null hypotheses have been formulated:

$\mathbf{H}_{\mathbf{0 1}}$ : Conditional accounting conservatism has no significant impact on ROA of listed NDMBs.

$\mathbf{H}_{\mathbf{0 2}}$ : Unconditional accounting conservatism has no significant impact on ROA of listed NDMBs.

The significance of this study seize to being only an extension of the accounting knowledge in the field of accounting conservatism by clarifying the concept of accounting conservatism. The study would also provides new insights analysis of the effects of accounting conservatism over bank performance. The findings are also expected to be useful to Shareholders (as owners), Creditors, Managers, Researchers and Regulatory bodies.

http://dx.doi.org/10.19085/journal.sijbpg041201 


\section{Literature review and Theoretical framework}

Accounting conservatism refers to the understatement of assets and revenues and the overstatement of liabilities and expenses. The recognition of losses should take place when it is assumed that these losses will occur, even when there is no legal claim for this. Recognition of gains on the other hand should only take place when there is a legal claim for it (Watts 2003). The conservatism principle states that in reporting the financial statements, a more pessimistic picture (understate) than an optimistic picture (overstate) will be described, due to this it is less probable that users of financial information will be hurt relying on prepared financial statements. The conservatism principle is one of the most significant and longstanding principles in the accounting. Conservatism has been influencing accounting for hundreds of years (Basu 1997). Sterling (1970), as cited by El allali, described conservatism as the most influential principle of valuation in accounting theory. Watts (2003) stated in his paper concerning conservatism in accounting, that future research on conservatism would be of big interest for the accounting science and practice.

Accounting conservatism is known to have two components, conditional conservatism and unconditional conservatism (Basu 2005, Beaver \& Ryan 2005, and Qiang 2007). When bad information is recognized in a timelier fashion than good information, conditional conservatism is mentioned; also known as news-dependent or ex-post conservatism (Beaver and Ryan 2005). Net assets are depreciated faster when receiving bad information than wroteup upon receiving good information under conditional conservatism. Conditional accounting conservatism refers to the application of accounting methods and policies that recognize bad news in earnings on a timelier basis than good news (Basu 1997; Pae 2007). Conditional conservatism is more coherent to contracting than unconditional conservatism. Conditional conservatism differs from unconditional conservatism, which is also known as newsindependent or ex-ante conservatism. In the case of unconditional conservatism firms recognize book values of net assets which are understated during their course of life due to the adoption of accounting standards and rules in bringing forth the financial statements. That's why unconditional conservatism is also referred to as balance-sheet conservatism (Beaver and Ryan 2005).

The profitability of a business organization would depend on the resources it owns and the obligations it has to meets. Companies carry out various activities to make profits, and to generate wealth for further growth. Like all businesses, banks profit by earning more money than what they pay in expenses. The major portion of a bank's profit comes from the fees that it charges for its services and the interest that it earns on its assets. Its major expense is the interest paid on its liabilities. The major assets of a bank are its loans to individuals, businesses, and other organizations and the securities that it holds, while its major liabilities are its deposits and the money that it borrows, either from other banks or by selling commercial paper in the money market. Profits can be measured as a return on assets and as a return on equity. Because of leverage, banks earn a much larger return on equity than they do on assets

Profitability is a bank's first line of defence against unexpected losses, as it strengthens its capital position and improves future profitability through the investment of retained earnings. An institution that persistently makes a loss will ultimately deplete its capital base, which in turn puts equity and debt holders at risk. Moreover, since the ultimate purpose of any profit-seeking organization is to preserve and create wealth for its owners, the bank's return on asset needs to be greater than its cost in order to create wealth for its owner. Although banking institutions have become increasingly complex, the key drivers of their performance remain earnings, efficiency, risk-taking and leverage. While it is clear that a bank must be able to generate "earnings" it is also important to take account of the composition and volatility of those earnings. "Efficiency" refers to the bank's ability to generate revenue from a given amount of assets and to make profit from a given source of income. "Risk-taking" is reflected in the necessary adjustments to earnings for the undertaken risks to generate them (e.g. Credit-risk cost over the cycle). "Leverage" might improve results in the upswing in the way it functions as a multiplier but, conversely, it can also make it more likely for a bank to fail, due to rare, unexpected losses.

Several papers such as Adah \& Thompson, (2016), Sanaa, (2016), Mudiarasan, Ali \& Ananda, (2010), El allaali, (2010), Halex (2007), Woolridge, Randall \& Gray, (2006), Maiturare (2004) and Evanoff \& Fortier (1988) have used the performance equation to examine the relationship between bank value and it determines. All those studies

http://dx.doi.org/10.19085/journal.sijbpg041201 
find evidence that banks follow dichotomous strategies for enhancing value as predicted by a lower risk, lower leverage strategy and a higher risk, higher leverage strategy.

Table 1 Summary Empirical Review

\begin{tabular}{|c|c|c|}
\hline Author & Year & Result \\
\hline $\begin{array}{l}\text { Ahmed, Billings, } \\
\text { Morton \& Stanford- } \\
\text { Harris. }\end{array}$ & 2002 & $\begin{array}{l}\text { Founds that higher levels of accounting conservatism are associated with lower } \\
\text { cost of debt and this association increases with borrowers' leverage and dividend } \\
\text { payments, suggesting that accounting conservatism protects lenders by constraining } \\
\text { dividend payments and mitigating other incentive conflicts between equity and debt } \\
\text { holders. }\end{array}$ \\
\hline Ahmed \& Duellman & 2007 & $\begin{array}{l}\text { More conservative firms show higher measures of profitability (such as net profit } \\
\text { margin and cash flow). They interpreted this evidence by stating that more } \\
\text { conservative firms invest more efficiently. }\end{array}$ \\
\hline El Allali & 2010 & $\begin{array}{l}\text { The relation between conservatism in the pre-crisis period and bank performance in } \\
\text { the crisis period was examined. The most significant result of the research was that } \\
\text { good performing banks in the crisis periods were conservative in the pre-crisis } \\
\text { period (at the } 10 \% \text { significance level). }\end{array}$ \\
\hline Biddle, Ma \& Song & 2012 & $\begin{array}{l}\text { Tests the relation between accounting conservatism and bankruptcy risk and find } \\
\text { asymmetric timeliness is associated with lower estimated bankruptcy risk. Their } \\
\text { sample consists of all firms regardless of their financial condition. By including } \\
\text { non-distressed firms in their sample, they address how conservatism affects default } \\
\text { risk but not recovery risk (Default risk is the probability of default while recovery } \\
\text { risk is the multiplication of default probability and recovery rate given default) }\end{array}$ \\
\hline Sanaa & 2016 & $\begin{array}{l}\text { The recommend increased oversight of the securities Exchange commission, the } \\
\text { organizers of the accounting profession and the official supervisors of organizing } \\
\text { the companies' work in Jordan, adopt the appropriate procedures in order to } \\
\text { encourage companies to commitment to an acceptable accounting conservatism } \\
\text { level }\end{array}$ \\
\hline Lawal \& Shehu & 2016 & $\begin{array}{l}\text { The results obtained from this research indicate that there is a significant } \\
\text { relationship between accounting conservatism and investment efficiency. The study } \\
\text { suggest that need to embrace the element of conservatism in to the accounting } \\
\text { regulatory framework, because of it role in constraining managers to act efficiently } \\
\text { in an investment monitoring and decision making. }\end{array}$ \\
\hline
\end{tabular}

Source: Developed by the Authors, 2017

\section{Methodology and Model Specification}

Predicated on the objectives of this study, it was believed that this study is quantitative in nature. Therefore, the philosophical point of view is post-positivism and research design used is quasi experimental. To describe the statistical association and relationship between variables in this study Ex post facto research design is used. In order to test the hypotheses of this study, Advance panel multiple regression analysis (panel corrected standard error) coupled with describtive statistics is employed. This is consistent with Beck \& Kazt, (1995, 2011), because of the effectiveness and efficiency of the technique in estimating the statistical relationship of one variable on another variable (more accurate estimation of standard error that gives much reliable beta coefficient values). The sample of the study consists of the 10 deposit money banks listed on the Nigerian Stock Exchange (NSE) for the period 2012 to 2016. The sampling method is systematic elimination (criteria sampling techniques), during which only banks under these conditions are selected: that Information about their recent 5 years has been delivered to Stock Exchange market. That their fiscal year terminates in December (the end of calendar year). And that only those that has commercial banking license with international authorization are selected.

\subsection{Variables Measurement}

In this paper the Basu model is chosen to measure the degree of conditional conservatism. Conditional conservatism is arising from management reporting and asymmetrical reaction against recognition of losses and unfulfilled profits (Basu, 1997; Pae 2007; El Allali, 2010 and Saeed et al, 2013). 


$$
N I_{\mathrm{it}}=\beta_{0}+\beta_{1} D R_{\mathrm{it}}+\beta_{2} R_{\mathrm{it}}+\beta_{3} R_{\mathrm{it}} * D R_{\mathrm{it}}+\varepsilon_{\mathrm{it}}
$$

Where:

NI represents the earnings yield, which are the earnings per share at the beginning of the fiscal year. It is measured by the earnings per share of bank $\mathrm{i}$, deflated by the beginning of the period share price $\left(\mathbf{X}_{\mathrm{it}} / \mathbf{P}_{\mathrm{it}-1}\right)$. $\mathrm{X}_{\mathrm{it}}$ represents the earnings per share of bank $\mathrm{i}$ and $\mathrm{P}_{\mathrm{it}-1}$ represents the beginning of the period share price of each bank I (Basu 1997; El Allali, 2010).

$\mathbf{R}$ is represented by the holding period returns of bank i including dividends (Basu 1997; El Allali, 2010). In this research the stock return at the beginning of the fiscal year is used.

DR is a dummy variable and is 1 when $R<0$ and is 0 otherwise. When $R$ is negative, this is assumed to be because $R$ is aggregating bad news about the future. The dummy variable has a value of 0 when $R$ is not aggregating future bad news, and has a value of 1 when $\mathrm{R}$ is incorporating future bad news.

$\boldsymbol{\beta 0}=$ Coefficient calculated by the regression model.

$\boldsymbol{\beta 1 - 3}=$ Coefficients of variables (slope).

$\boldsymbol{\varepsilon}=$ the residual error from the regression model.

Unconditional conservatism is a type of conservatism affected by accounting standards and legal requirements. To measure it, we calculate total accruals to total assets. The negative items showed high degree of conservatism because the result of unconditional conservatism is underestimating profit and the reported profit is lower than cash flows of the company (Givoly \& Hayn, 2000; Ahmad \& Dulman, 2007, Saeed et al, 2013 and Lawal \& Shehu, 2016).

$$
U C-A C C_{\mathrm{it}}=T A C C_{\mathrm{it}} / T A_{\mathrm{it}}(-1)
$$

Where

UC-ACC $=$ Unconditional conservatism

TACC $=$ Total accruals $\left(\right.$ TACC $_{i t}=$ net income before extraordinary items $\mathrm{it}_{\mathrm{it}}-$ operational cash flow $\left.\mathrm{w}_{\mathrm{it}}\right)$

$\mathbf{T A}=$ Book value of total assets

For measuring the bank performances in this paper the ROA (return on asset) is used. The ROA measures a company's efficiency at making gains from each part of asset (Woolridge et al, 2006; El Allali, 2010, PwC, 2011 and Adah \& Thompson, 2016). It is calculated as follows:

ROA =

Fee Income + Net Interest Income - Operating Costs

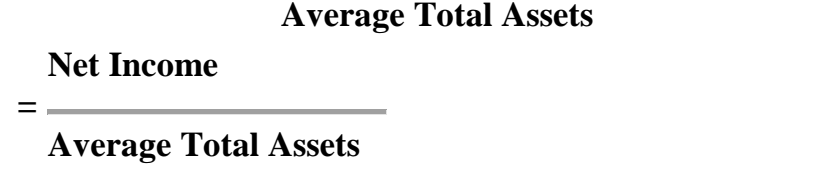

Because income is calculated over a time period, but assets, as a balance sheet factor, are determined at a particular time, average assets are used:

Average Total Assets

Total Assets at End of Fiscal Year + Total Assets at Start of Fiscal Year

2

(Note: Herein we will refer to Average Total Assets as simply Bank Assets) 
Table 2 Summary of Variable measurement

\begin{tabular}{ll}
\hline Variable & Measurement \\
\hline 1. Bank Performance (ROA) & $R O A=$ Net income $/ A$ Average Total Asset by PwC (2011) \\
2. Conditional conservatism (C-ACC) & $N I_{\mathrm{it}}=\beta_{0}+\beta_{1} D R_{\mathrm{it}}+\beta_{2} R_{\mathrm{it}}+\beta_{3} R_{\mathrm{it}} * D R_{\mathrm{it}}+\varepsilon_{\mathrm{it}}$ by Basu, (1997) \\
3. Unconditional conservatism (UC-ACC) & $U C-A C C_{\mathrm{it}}=T A C C_{\mathrm{it}} / T A_{\mathrm{it}}(-1)$ by Saeed et al, (2013) \\
4 Firm size (SIZE) & SIZE $=$ Log of total asset \\
\hline
\end{tabular}

Source: Developed by the Author in line with literature

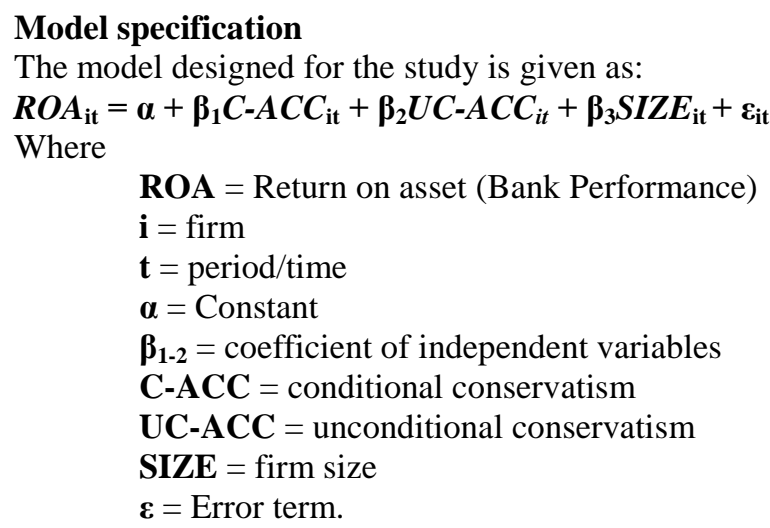

\section{Result and Discussion}

In this section, the study's results are presented and discussed. The time-series and cross-sectional nature of panel data usually lead to the production of bias estimators when OLS regression is employed. The usual solution to this case was to employ Fixed and Random effects regression, however Beck \& Katz (2011) argues, that this solution too tends to create a problem of under-estimation standard errors seriously making beta coefficient value unrealistic thus, they suggested panel corrected standard errors regression (PCSE) take care of that inefficiency. All relevant tests are carried out alongside the regression model (PCSE). The discriptive statistics are first presented, correlation matrix then followed by the regression results.

Table 3: Descriptive Statistics of the Variables

\begin{tabular}{lllllll}
\hline VARIABLES & Min & Max & Mean & SD & Skewness & Kurtosis \\
\hline ROA & 0.92 & 692.35 & 227.53 & 183.45 & 1.3162 & 3.7337 \\
C-ACC & 1.51 & 1995.23 & 397.35 & 337.23 & 2.4542 & 11.2736 \\
UC-ACC & -122.33 & 209.21 & 1.32 & 39.86 & 2.5100 & 17.9871 \\
SIZE & -0.1059 & 0.1644 & 0.053 & 0.0525 & -0.0389 & 3.6241 \\
\hline
\end{tabular}

Source: STATA OUTPUT (see appendix)

Table 3 show that financial performance has an average value of 227.53, with standard deviation of 183.45 , minimum value of 0.92 , and 692.35 as the maximum value. This is an indication that the data is normally distributed and is fit to produce a reliable result, becouse the mean is greater than standard deviation even though there is an element of outlier issue in the data, the issues may not causes any problem to the inferential statistics. The Table 3 also shows that the Accounting conservatism (C-ACC) have an average value of 397.35 with standard deviation of 337.23, and the minimum and maximum value of 1.51 and 1995.23 respectively. This shows that the data is not dispersed from the mean because the standard deviation is lower than the mean. Finally, the average Accounting conservatism (UC-ACC), which is The total accruals to total assets is 1.32, ranging between -122.33 to 209.21. Here also, there is an indication that the data are not positively skewed and are fit to produce result that is reliable. 
Table 4 Correlation Matrix

\begin{tabular}{lllll}
\hline VARIABLES & ROA & C-ACC & UC-ACC & SIZE \\
\hline ROA & 1.0000 & & & \\
C-ACC & $0.6962^{* * * *}$ & 1.0000 & & \\
UC-ACC & $-0.2492^{*}$ & 0.0670 & 1.0000 & 1.0000 \\
SIZE & $-0.4220^{* * *}$ & $-0.3862^{* * *}$ & -0.0669 & \\
\hline
\end{tabular}

Source: STATA OUTPUTS (see appendix)

*** significant at 1\%, "* significant at 5\%, "significant at 10\%

The correlation matrix Table 4 shows the relationship between all variables in the study model (conditional accounting conservatism, unconditional accounting conservatism, firm size and the financial performance. The result reveals that firm size is Negatively correlated with all other variables. This calls for an investigation of the possibility of multicollinearity. However, the results VIF Test proved the absence of perfect multicollinearity among the variables, because on average variance inflation factor (Mean VIF) is 1.12. The rule of thumb for the Tolerance Value is that any value of 1.0 and above implies the presence of perfect multicollinearity in the estimates, while for the Variance Inflation Factor a value of 10 and above is an indication of perfect multicollinearity. Similarly, the panel is a micro-panel which the problem of autocorrelation may not cause much harm on the findings.

Table 5. Summary of Regression Results

\begin{tabular}{lllll}
\hline Variable & Coefficient & Std. Err. & Z value & P>|Z| \\
\hline Constant & 126.9243 & 33.72872 & 3.76 & 0.000 \\
C-ACC & 0.3489676 & 0.0699247 & 4.99 & 0.000 \\
UC-ACC & -1.404327 & 0.5587722 & -2.51 & 0.012 \\
SIZE & -679.1312 & 311.4379 & -2.18 & 0.029 \\
R2 & & & $\mathbf{0 . 6 0 4 8}$ \\
Wald Chi $^{2}$ & & & & $\mathbf{3 9 . 7 2}$ \\
Prob $>\mathbf{C h i}^{2}$ & & & & $\mathbf{0 . 0 0 0}$ \\
Autocorrelation & & & & No autocorrelation \\
\hline
\end{tabular}

Source: STATA OUTPUTS (see appendix)

The Table 5 presents the regression results of PCSE models. The multiple coefficient of determination $\mathrm{R}^{2}$ from table indicates that the predictor variables (conditional accounting conservatism and unconditional accounting conservatism) explained $60.48 \%$ of the variations in the dependent variable, financial performance of the listed NDMBs in Nigeria, $\left(\mathrm{R}^{2}\right.$ value of 0.6048$)$. The result also shows that the model is fitted as evidenced by the WaldStatistics of 39.72 which is significant at $1 \%$ level of significance $\left(\mathrm{Prob}>\mathrm{Chi}^{2} 0.0000\right)$.

The results in Table 5, shows that conditional accounting conservatism (C-ACC) has a statistically significant positive impact on the bank performance (ROA) of listed NDMBs in Nigeria as indicated by the z-value of 4.99 with P-value 0.000 which is $1 \%$ level of significance. This implies that, conditional accounting conservatism (CACC) can significantly improves the performance of listed NDMBs in Nigeria, during the period covered by the study. Thus, the null hypothesis $\left(\mathrm{HO}_{1}\right)$ which states that, $\mathrm{C}-\mathrm{ACC}$ has no significant impact on financial performance of listed NDMBs in Nigeria is rejected. This paper showed that C-ACC occurs during the full sample period which implies that the NDMBs were conservative in the period 2012-2016; therefore C-ACC has information advantages that reduce inefficiency and effectiveness in business activities. This finding is in accord with researches by Lawal \& Shehu (2016), Garcia Lara et al (2016), Zahra \& fatemeh (2015), Mahmoudabadi \& Mehtari (2012) and Lalbar et al (2012), Thus, the implication of this finding is that when performance decreases, the stakeholders become worried and consider it as a result of mis-management by managers of the confidential information which would trigger agitation for more conservative methods to preserve their interest.

The Table 5 also shows that the effect of unconditional accounting conservatism (UC-ACC) on the financial performance of listed deposit money banks in Nigeria is significantly negative, considering the $\mathrm{z}$-value of -2.51 and p-value of 0.012 (5\% level of significance). Which infer that, when UC-ACC increases, banks performance would reduce during the sampled period, and the reasons could have to do with the fact that banks are pressured to show 
more positive information to diminish the negative effects of the financial issues on ground (recession). Based on this, we reject the null hypothesis $\left(\mathrm{HO}_{2}\right)$ which states that UC-ACC has no significant impact on financial performance of listed NDMBs in Nigeria. Therefore, it can be generally said that banks with higher unconditional conservatism have lower financial performance. The implication of this result is that UC-ACC causes decrease in the performance of the banks which the benefactors may find unsatisfactory. However, adopting conservative decisions has advantages such as signing effective contracts, decreased or delayed taxation, eliminating the managers' partiality, reduced political expenses, less tension between creditors and shareholders, reduces pressure and competition risks, and increased quality of financial data.

\section{Conclusion and Recommendation}

Based on the key findings of this research, the study concludes as follows

i. There is significant positive relationship between conditional accounting conservatism and performance of listed NDMBs in Nigeria. Therefore conditional conservatism has information advantages that reduce inefficiency in banks business activities.

ii. There is significant negative relationship between unconditional accounting conservatism and performance of listed NDMBs in Nigeria Therefore Higher unconditional conservatism causes reduction in banks performance.

iii. Overall the study concluded that there is a significant relationship between accounting conservatism and bank performance.

In line with the findings and conclusion of the study, it is recommended that:

i. Managers of NDMBs should use conditional conservatism as a means to manage information asymmetry in their financial reporting strategies. This is because of the positive impact of conditional conservatism on the banks performance. Accounting conservatism is often characterized as an equilibrium reaction used to mitigate value reduction resulting from information asymmetry or private information that arises between investors and managers

ii. Since unconditional conservatism is having negative relationship with banks performance, it is recommended that accounting standard setters and bank regulators should consider these effects when designing rules and regulations for banks. Because it has been clearly observed that there are many regulations on the banks activities which are systematically affecting their performance by reducing their returns on asset. According to unconditional conservatism, more assets reduction provision leads to reduction of assets book value which in turn results in increasing free cash flows that may result in high earnings quality.

iii. Finally, it is recommended that similar research could be performed in another domain or with a larger dataset of banking sector for instance more years with bigger sample size to see if the relationship between conservatism and performance still holds.

\section{References}

[1] Accounting Principles Board (APB), (1965). Accounting Principles Board Opinion No. 6, Status of Accounting Research Bulletins. American Institute of Certified Public Accountants (AICPA), New York.

[2] Accounting Principles Board (APB), (1973). Accounting Principles Board Opinion No. 30, Reporting the results of operations. American Institute of Certified Public Accountants (AICPA), New York.

[3] Adah Abu \& Thompson Samaila, (2016). Limitation of Returns on Asset in measuring Banks performance in Nigeria. International Journal of management and social sciences research review, 1 (2), 31-38

[4] Ahmed, A. S., Billings B. K., Morton R. M. \& Stanford-Harris M., (2002). The role of accounting conservatism in mitigating bondholder-shareholder conflicts over dividend policy and in reducing debt costs. The Accounting Review 77(4), 867-890.

[5] Ahmed, A.S. \& Duellman S., (2007a). Evidence on the role of accounting conservatism in monitoring managers' investment decisions. Working paper, Texas A \& M University.

[6] Ahmed, A.S. \& Duellman S., (2007b). Evidence on the role of accounting conservatism in corporate governance. Journal of accounting and Economics, 43, $41-437$.

[7] Basu, S. (1995). Conservatism and the asymmetric timeliness of earnings. Ph.D. thesis. University of Rochester, New York.

[8] Basu, S. (2005). Discussion of "Conditional and unconditional Conservatism: Concepts and Modeling", Review of Accounting Studies, 10, 311-321

http://dx.doi.org/10.19085/journal.sijbpg041201 
[9] Basu, S. (1997), The conservatism principle and the asymmetric timeliness of earnings. Journal of Accounting and Economics, 24, (1), 3 - 37.

[10] Beaver W.H., \& Ryan S.G., (2005). Conditional and unconditional conservatism: Concepts and modeling. Review of Accounting Studies 10, 269-309.

[11] Beck N., and Katz J. N., (1995). What to do (and not to do) with time-series cross-section data. American Political Science Review 89, 634-647.

[12] Biddle, G., Ma, M., Song, F., (2013). Accounting Conservatism and Bankruptcy Risk. Working Paper, October 2013.

[13] Bushman R.M. \& Smith A. J. (2001). Financial accounting information and corporate governance. Journal of Accounting and Economics, 32, 237-333.

[14] El Allali, Tarik (2010). The relationship between accounting conservatism and West-European bank performance during the recent financial crisis, an empirical study of conservatism in the West-European banking sector. Master thesis Erasmus University Rotterdam.

[15] Evanoff, D., \& Fortier,D.L. (1988). Re-evaluation of the structure conduct-performance paradigm in banking. Journal of financial services Research, 1.

[16] Financial Accounting Standard Board, Qualitative Characteristics of Accounting Information. Statement of Financial Accounting Concept No. 2, Stamford, CT. (1980).

[17] Garcia lara J.M., Garcia Osama B.,\& Penalva F., (2016). Accounting conservatism and investment efficiency. Journal of accounting and economics, 61(1).

[18] Givoly, D. and C. Hayn (2000). The changing time-series properties of earnings, cash flows and accruals: Has financial reporting become more conservative? Journal of Accounting and Economics, 29, (3), 287-320.

[19] Halex , T. S. (2007). Measuring banks performance. Journal of economic, social and management sciences.

[20] Lalbar A., Mehdi G., Hosein P. M., \& karamali M., (2012). A study of the relationship between accounting conservatism and investment efficiency. Journal of basic and applied scientific research. 2(6), 5719-5725.

[21] Lambert R.A., Leuz C., \& Verrecchia R. E., (2007). Accounting information, disclosure and the cost of capital. Journal of Accounting Research, 45(2), 385-420.

[22] Lawal A. \& Shehu U. H., (2016). Accounting conservatism and Investment efficiency of listed Nigeria Conglomerates Firms. Scholedge International Journal of Business Policy \& Governance, 3(11), 167-177.

[23] Mahmoodabadi H. \& Mehtari Z., (2012). The association between Accounting conservatism and investment efficiency. Journal of accounting advances (JAA), 3(2), 15-17.

[24] Maiturare, M. N. (2004). An evaluation of the structure condunct performance paradigm in banking: A study of Nigerian commercial banks. The Nigerian Journal of Administrative studies, A.B.U., Zaria, 2 (1).

[25] Mudiarasan, K., Ali, S. S. \& Ananda, S. (2010). Measurement of Islamic Banks performance using a Sharia conformity and profitability model.

[26] Pae J. (2007). Unexpected Accruals and Conditional Accounting Conservatism, Journal of Business Finance \& Accounting, 34 (5) \& (6), 681-704.

[27] Qiang X., (2007). The effects of contracting, litigation, regulation, and tax costs on conditional and unconditional conservatism: Cross-sectional evidence at the firm level. The Accounting Review, 82(3), 759-796.

[28] Saeed A., Khadije R., \& Mohammad A., (2013). Relations between unconditional and conditional accounting conservatism with bankruptcy risk in companies listed in Tehran stock exchange. International research journal of applied and basic sciences, 4(10), 3649-3657.

[29] Watts, R. L. (2003a). Conservatism in Accounting Part I: Explanations and Implications. Accounting Horizons 17, $207-$ 221.

[30] Watts, R.L. (2003b), Conservatism in accounting. Part II: evidence and research opportunities, Accounting Horizons, 7,(4), 287-301.

[31] Woolridge, J. Randall and Gray, Gary (2006). Applied Principles of Finance

[32] Zahra P., \& Fatemeh M., (2015). The effect of financial constaint on the relationship between overinvestment and conditional and unconditional accounting conservatism. J. Appl. Environ. Biol. Sci., 5(113), 166-174. 


\section{Appendix}

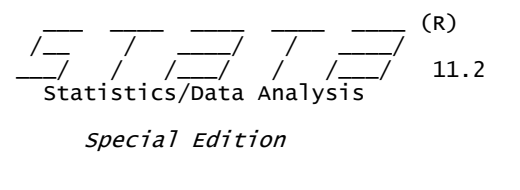

Copyright 1985-2009 Statacorp LP

Statacorp

4905 Lakeway Drive

College Station, Texas 77845 USA

800-STATA-PC http://www.stata.com

stata@stata.com

979-696-4601 (fax)

Single-user stata license expires 31 Dec 9999:

Seria1 number: 71606281563

Licensed to: STATAForA11

Notes:

1. (/m\# option or - set memory-) $50.00 \mathrm{MB}$ allocated to data

2. (/v\# option or - set maxvar-) 5000 maximum variables

. edit

. *6 variables, 50 observations pasted into data editor)

- describe

Contains data

obs:

vars:

size:

50

1,150 (99.9\% of memory free)

\begin{tabular}{|c|c|c|c|c|}
\hline variable name & $\begin{array}{c}\text { storage } \\
\text { type }\end{array}$ & $\begin{array}{l}\text { display } \\
\text { format }\end{array}$ & $\begin{array}{l}\text { value } \\
\text { labe1 }\end{array}$ & variable label \\
\hline id & byte & $\% 8.0 \mathrm{~g}$ & & ID \\
\hline years & int & $\% 8.0 \mathrm{~g}$ & & YEARS \\
\hline roa & float & $\% 8.0 \mathrm{~g}$ & & ROA \\
\hline cacc & float & $\% 8.0 \mathrm{~g}$ & & $C-A C C$ \\
\hline ucacc & float & $\% 8.0 \mathrm{~g}$ & & UC-ACC \\
\hline size & float & $\% 8.0 \mathrm{~g}$ & & SIZE \\
\hline
\end{tabular}

Sorted by:

Note: dataset has changed since last saved

- summarize roa cacc ucacc size

\begin{tabular}{r|rrrrr} 
Variable & obs & Mean & Std. Dev. & Min & Max \\
\hline roa & 50 & 227.5358 & 183.4474 & .92 & 692.35 \\
cacc & 50 & 397.3546 & 337.2303 & 1.51 & 1995.23 \\
ucacc & 50 & 1.316867 & 39.86276 & -122.332 & 209.2056 \\
size & 50 & .053308 & .0525821 & -.1059 & .1644
\end{tabular}

. summarize roa cacc ucacc size, detai1

\begin{tabular}{|c|c|c|c|c|}
\hline \multicolumn{5}{|c|}{ ROA } \\
\hline $\begin{array}{r}1 \% \\
5 \% \\
10 \% \\
25 \%\end{array}$ & $\begin{array}{r}\text { Percentiles } \\
.92 \\
12.25 \\
95.845 \\
118.51\end{array}$ & $\begin{array}{r}\text { Sma71est } \\
.92 \\
7.86 \\
12.25 \\
24.91\end{array}$ & $\begin{array}{l}\text { Obs } \\
\text { Sum of wgt. }\end{array}$ & $\begin{array}{l}50 \\
50\end{array}$ \\
\hline $50 \%$ & 144.775 & Largest & $\begin{array}{l}\text { Mean } \\
\text { std. Dev. }\end{array}$ & $\begin{array}{l}227.5358 \\
183.4474\end{array}$ \\
\hline $\begin{array}{l}75 \% \\
90 \% \\
95 \% \\
99 \%\end{array}$ & $\begin{array}{r}331.19 \\
559.155 \\
660.08 \\
692.35\end{array}$ & $\begin{array}{l}656.68 \\
660.08 \\
682.34 \\
692.35\end{array}$ & $\begin{array}{l}\text { Variance } \\
\text { Skewness } \\
\text { Kurtosis }\end{array}$ & $\begin{array}{l}33652.95 \\
1.316105 \\
3.733752\end{array}$ \\
\hline & & $\mathrm{C}-\mathrm{AC}$ & & \\
\hline
\end{tabular}

\begin{tabular}{|c|c|c|c|c|}
\hline $\begin{array}{r}1 \% \\
5 \% \\
10 \% \\
25 \%\end{array}$ & $\begin{array}{c}\text { Percentiles } \\
1.51 \\
114.24 \\
144.74 \\
201.49\end{array}$ & $\begin{array}{r}\text { Sma11est } \\
1.51 \\
107.61 \\
114.24 \\
131.48\end{array}$ & $\begin{array}{l}\text { obs } \\
\text { Sum of wgt. }\end{array}$ & $\begin{array}{l}50 \\
50\end{array}$ \\
\hline $50 \%$ & 250.225 & & Mean & $\begin{array}{l}397.3546 \\
337.2303\end{array}$ \\
\hline $\begin{array}{l}75 \% \\
90 \% \\
95 \% \\
99 \%\end{array}$ & $\begin{array}{r}541.43 \\
830.755 \\
856.07 \\
1995.23\end{array}$ & $\begin{array}{r}854.91 \\
856.07 \\
1067.39 \\
1995.23\end{array}$ & $\begin{array}{l}\text { Variance } \\
\text { Skewness } \\
\text { Kurtosis }\end{array}$ & $\begin{array}{l}113724.3 \\
2.454297 \\
11.27362\end{array}$ \\
\hline
\end{tabular}


UC-ACC

\begin{tabular}{|c|c|c|c|c|}
\hline $\begin{array}{r}1 \% \\
5 \% \\
10 \% \\
25 \%\end{array}$ & $\begin{array}{c}\text { Percentiles } \\
-122.332 \\
-30.2924 \\
-25.83979 \\
-16.10733\end{array}$ & $\begin{array}{r}\text { Sma11est } \\
-122.332 \\
-37.74278 \\
-30.2924 \\
-29.45627\end{array}$ & $\begin{array}{l}\text { Obs } \\
\text { Sum of wgt. }\end{array}$ & $\begin{array}{l}50 \\
50\end{array}$ \\
\hline $\begin{array}{l}50 \% \\
75 \% \\
90 \% \\
95 \% \\
99 \%\end{array}$ & $\begin{array}{l}.0450597 \\
6.833747 \\
19.88554 \\
32.92167 \\
209.2056\end{array}$ & $\begin{array}{r}\text { Largest } \\
21.96992 \\
32.92167 \\
93.29108 \\
209.2056\end{array}$ & $\begin{array}{l}\text { Mean } \\
\text { Std. Dev. } \\
\text { Variance } \\
\text { Skewness } \\
\text { Kurtosis }\end{array}$ & $\begin{array}{r}1.316867 \\
39.86276 \\
1589.04 \\
2.510026 \\
17.98715\end{array}$ \\
\hline \multicolumn{5}{|c|}{ SIZE } \\
\hline $\begin{array}{r}1 \% \\
5 \% \\
10 \% \\
25 \%\end{array}$ & $\begin{array}{c}\text { Percentiles } \\
-.1059 \\
-.0165 \\
-.00365 \\
.0283\end{array}$ & $\begin{array}{r}\text { Sma11est } \\
-.1059 \\
-.0403 \\
-.0165 \\
-.013\end{array}$ & $\begin{array}{l}\text { Obs } \\
\text { Sum of wgt. }\end{array}$ & $\begin{array}{l}50 \\
50\end{array}$ \\
\hline $50 \%$ & .0421 & Largest & $\begin{array}{l}\text { Mean } \\
\text { Std. Dev. }\end{array}$ & $\begin{array}{r}.053308 \\
.0525821\end{array}$ \\
\hline $\begin{array}{l}75 \% \\
90 \% \\
95 \% \\
99 \%\end{array}$ & $\begin{array}{l}.0821 \\
.1304 \\
.1479 \\
.1644\end{array}$ & $\begin{array}{l}.1406 \\
.1479 \\
.1508 \\
.1644\end{array}$ & $\begin{array}{l}\text { Variance } \\
\text { Skewness } \\
\text { Kurtosis }\end{array}$ & $\begin{array}{r}.0027649 \\
-.0388641 \\
3.624127\end{array}$ \\
\hline
\end{tabular}

- pwcorr roa cacc ucacc size, sig

\begin{tabular}{r|rrrr} 
& roa & cacc & ucacc & size \\
\hline roa & 1.0000 & & & \\
& & & & \\
cacc & 0.6962 & 1.0000 & & \\
& 0.0000 & & & \\
ucacc & -0.2492 & 0.0670 & 1.0000 & \\
& 0.0810 & 0.6440 & & \\
size & -0.4220 & -0.3862 & -0.0669 & 1.0000 \\
& 0.0023 & 0.0056 & 0.6441 &
\end{tabular}

- regress roa cacc ucacc size

\begin{tabular}{|c|c|c|c|c|c|c|c|}
\hline Source & SS & $d f$ & \multicolumn{2}{|c|}{ MS } & & \multirow{3}{*}{$\begin{array}{l}\text { Number of obs } \\
\text { F( } 3, \quad 46) \\
\text { Prob }>F \\
\text { R-squared } \\
\text { Adj R-squared } \\
\text { Root MSE }\end{array}$} & \multirow{3}{*}{$\begin{array}{lr}= & 50 \\
= & 23.47 \\
= & 0.0000 \\
= & 0.6048 \\
= & 0.5791 \\
= & 119.02\end{array}$} \\
\hline $\begin{array}{r}\text { Mode1 } \\
\text { Residua1 }\end{array}$ & $\begin{array}{l}997356.715 \\
651638.025\end{array}$ & $\begin{array}{r}3 \\
46\end{array}$ & $\begin{array}{r}332 \\
14\end{array}$ & $\begin{array}{l}2.238 \\
6.044\end{array}$ & & & \\
\hline Tota1 & 1648994.74 & 49 & 336 & .9539 & & & \\
\hline roa & Coef. & std. & Err. & $\mathrm{t}$ & $P>|t|$ & [95\% Conf. & Interval] \\
\hline $\begin{array}{r}\text { cacc } \\
\text { ucacc } \\
\text { size } \\
\text { _cons }\end{array}$ & $\begin{array}{r}3489676 \\
-1.404327 \\
-679.1312 \\
126.9243\end{array}$ & $\begin{array}{l}.054 \\
.427 \\
350 . \\
37.6\end{array}$ & $\begin{array}{l}7157 \\
9255 \\
9131 \\
5661\end{array}$ & $\begin{array}{r}6.38 \\
-3.28 \\
-1.94 \\
3.37\end{array}$ & $\begin{array}{l}0.000 \\
0.002 \\
0.059 \\
0.002\end{array}$ & $\begin{array}{r}.2388307 \\
-2.265696 \\
-1385.483 \\
51.12552\end{array}$ & $\begin{array}{r}.4591045 \\
-.5429578 \\
27.22012 \\
202.7232\end{array}$ \\
\hline
\end{tabular}

. vif

\begin{tabular}{r|rr} 
Variable & VIF & 1 VIF \\
\hline cacc & 1.18 & 0.849134 \\
size & 1.18 & 0.849137 \\
ucacc & 1.01 & 0.993531 \\
\hline Mean VIF & 1.12 &
\end{tabular}

- xtset id years

panel variable: id (strongly balanced)

time variable: years, 2012 to 2016

de1ta: 1 unit 


\begin{tabular}{|c|c|c|c|c|c|c|}
\hline \multicolumn{4}{|c|}{$\begin{array}{ll}\text { Group variable: } & \text { id } \\
\text { Time variable: } & \text { years } \\
\text { Panels: } & \text { correlated (balanced) } \\
\text { Autocorrelation: } & \text { no autocorrelation }\end{array}$} & \multicolumn{2}{|c|}{$\begin{array}{l}\text { Number of obs } \\
\text { Number of groups } \\
\text { Obs per group: } \begin{array}{r}\text { min } \\
\text { avg } \\
\max \end{array}\end{array}$} & \multirow{2}{*}{$\begin{array}{r}50 \\
10 \\
5 \\
5 \\
5 \\
0.6048 \\
39.72 \\
0.0000\end{array}$} \\
\hline $\begin{array}{l}\text { Estimated cov } \\
\text { Estimated aut } \\
\text { Estimated coe }\end{array}$ & $\begin{array}{ll}\text { iances } & = \\
\text { orrelations } & = \\
\text { icients } & =\end{array}$ & $\begin{array}{r}55 \\
0 \\
4\end{array}$ & & $\begin{array}{l}\text { R-squa } \\
\text { Wald C } \\
\text { Prob > }\end{array}$ & $\begin{array}{ll}\mathrm{d} & = \\
2(3) & = \\
\operatorname{hi2} & =\end{array}$ & \\
\hline roa & Coef. $^{\text {Pan }}$ & $\begin{array}{l}\text { nel-correct } \\
\text { Std. Err. }\end{array}$ & z & $P>|z|$ & {$[95 \%$ Conf } & Interva1] \\
\hline $\begin{array}{r}\text { cacc } \\
\text { ucacc } \\
\text { size } \\
\text { _cons }\end{array}$ & $\begin{array}{r}.3489676 \\
-1.404327 \\
-679.1312 \\
126.9243\end{array}$ & $\begin{array}{l}.0699247 \\
.5587722 \\
311.4379 \\
33.72872\end{array}$ & $\begin{array}{r}4.99 \\
-2.51 \\
-2.18 \\
3.76\end{array}$ & $\begin{array}{l}0.000 \\
0.012 \\
0.029 \\
0.000\end{array}$ & $\begin{array}{r}.2119178 \\
-2.499501 \\
-1289.538 \\
60.81727\end{array}$ & $\begin{array}{r}.4860175 \\
-.3091537 \\
-68.72412 \\
193.0314\end{array}$ \\
\hline
\end{tabular}

